\title{
Genetic Analysis of Fluorescent Pigment Production in Pseudomonas syringae pv. syringae
}

\author{
BY JOYCE E. LOPER, $†$ CINDY S. ORSER, \\ NICKOLAS J. PANOPOULOS AND MILTON N. SCHROTH* \\ Department of Plant Pathology, University of California, Berkeley, CA 94720, USA
}

(Received 10 November 1983; revised 25 January 1984)

\begin{abstract}
Genes involved in the biosynthesis of a fluorescent pigment by Pseudomonas syringae pv. syringae ( $P$. s. syringae) JL2000 were investigated. A genomic library of this strain was constructed using the broad host range cosmid vector, pLAFR1. Nonfluorescent $\left(\mathrm{Flu}^{-}\right)$mutants of JL2000, defective in the biosynthesis of a fluorescent pigment, were obtained after ethyl methanesulphonate mutagenesis. Individual recombinant plasmids from the genomic library were introduced into $\mathrm{Flu}^{-}$mutants. Of a total of $146 \mathrm{Flu}^{-}$mutants, 36 were restored to fluorescence following matings with individual recombinant colonies in the genomic library. Four separate fluorescence restoration groups, each comprised of 5 to $11 \mathrm{Flu}^{-}$mutants restored to fluorescence by one of four structurally distinct recombinant plasmids, were identified. Whereas the $36 \mathrm{Flu}^{-}$mutant strains differed in their abilities to grow on an iron-deficient medium, wild-type $P$. s. syringae strain JL2000 and all $\mathrm{Flu}^{+}$transconjugants from these 36 crosses grew on an iron-deficient medium. These results indicate that at least four genes or gene clusters are involved in the production of a fluorescent pigment of $P$. s. syringae strain JL2000. These genes, with few exceptions, also control the ability of strain JL 2000 to grow under ironlimiting conditions.
\end{abstract}

\section{INTRODUCTION}

Many strains of fluorescent pseudomonads are important agriculturally as soil saprophytes, foliar epiphytes, or phytopathogens. Some of these bacteria colonize the roots of agricultural plants and may be considered beneficial, deleterious, or neutral to plant growth (Schroth \& Hancock, 1981, 1982). A number of beneficial strains taxonomically classified in the Pseudomonas fluorescens-putida group have been used as seed inoculants of agricultural plants to increase plant growth (Suslow, 1982; Burr \& Caesar, 1984), or to control biologically one or more soil-borne phytopathogens (Howell \& Stipanovic, 1979, 1980; Scher \& Baker, 1982; Weller \& Cook, 1983). Other strains, classified as pathovars of Pseudomonas syringae van Hall, are bacterial epiphytes prevalent on leaf surfaces, with the capability of inciting disease and frost injury on a wide variety of host plants (Schroth et al., 1981).

The singular characteristic common to all strains of fluorescent pseudomonads is the production of an extracellular, water-soluble, yellow-green pigment which fluoresces under UV irradiation. The fluorescent pigment produced by $P$. fluorescens Migula functions as a siderophore, as characterized by its synthesis only under iron-limiting conditions (Lenhoff, 1963), specific and high affinity for $\mathrm{Fe}^{3+}$ (Meyer \& Abdallah, 1978), and role in transport of $\mathrm{Fe}^{3+}$ into the bacterial cell (Meyer \& Hornsperger, 1978). The siderophores or related substances produced by $P$. fluorescens include both fluorescent pigments: pseudobactin (Teintze

† Present address: Chevron Chemical Co., 940 Hensley St, Richmond, CA 94804, USA.

Abbreviations: KBM, King's Medium B (King et al., 1954); ĒDDA, ethylenediaminedi(o-hydroxyphenylacetic acid). 
et al., 1981), pyoverdine (Meyer \& Abdallah, 1978; Meyer \& Hornsperger, 1978; Philson \& Llinas, 1982a, b) and compound S (McCracken \& Swinburne, 1979); and nonfluorescent compounds: ferribactin (Maurer et al., 1968), pseudobactin A (Teintze \& Leong, 1981), and unidentified purple compounds (Philson \& Llinas, 1982a).

The crystal and molecular structure of ferric pseudobactin, a fluorescent pigment-siderophore from Pseudomonas fluorescens strain B10, has been shown by X-ray crystallography to consist of a linear hexapeptide of both L-and D-amino acids attached to a fluorophoric quinoline derivative (Teintze et al., 1981). NMR spectroscopy analysis of the pyoverdine compound produced by $P$. fluorescens ATCC 13525 suggests a striking similarity to the structure of pseudobactin, with a possible discrepancy in that the succinyl diamide chain attached to the quinoline moiety may not be the same for pseudobactin as for pyoverdine (Philson \& Llinas, 1982b). The fluorescent chromophore of pseudobactin (Teintze et al., 1981) and of pyoverdine (Philson \& Llinas, 1982b) is analogous to that of the Azotobacter pigment (Bulen \& Le Comte, 1962; Corbin et al., 1970). The structure of the fluorescent pigment of the phytopathogenic species, $P$. syringae, is unknown, but it has been suggested that at least minor structural differences exist among pigments produced by various species of fluorescent pseudomonads (Meyer \& Hornsperger, 1978).

The role of siderophores in the ecology of plant-associated Pseudomonas species recently has become an area of active research. Pseudomonas strains producing siderophores exhibit in vitro antibiosis against indicator bacterial or fungal strains (Kloepper et al., 1980; Hemming et al., 1982; Misaghi et al., 1982) which is influenced by addition of iron to the culture medium. The positive influence on plant growth induced by beneficial strains is considered in part a result of the production of extracellular siderophores which complex the iron in the root environment, making it less available to competing microflora, thus alleviating plant stresses induced by soilborne phytopathogens (Kloepper et al., 1980; Scher \& Baker, 1982).

The suggested involvement of siderophores in plant growth promotion and biological control resulting from seed inoculation with beneficial Pseudomonas strains has generated interest in the genetics of siderophore production and regulation in these organisms. This study was initiated to identify genes involved in the production of the fluorescent pigment of Pseudomonas syringae pv. syringae (hereafter referred to as $P$. s. syringae).

A broad host range cloning vector, pLAFR1, developed by Ditta et al. (1980) has been used in cloning experiments with non-enteric bacteria (Friedman et al., 1982) including the pseudomonads (Orser et al., 1983). This vector, a cosmid, is suitable for in vitro packaging of recombinant molecules since it contains the cohesive ends site (cos) of bacteriophage $\lambda$. RK2, the parental plasmid of pLAFR1, is known to replicate in several pathovars of $P$. syringae (Panopoulos et al., 1978). Genomic libraries of $P$. s. syringae strains constructed with this vector proved useful in the genetic analysis of fluorescent pigment biosynthesis in $P$. s. syringae merodiploids.

Preliminary aspects of this work have been reported previously (Loper et al., 1983; Orser et al., 1983).

\section{METHODS}

Bacterial strains and plasmids. The bacterial strains, resident plasmids, relevant phenotypic characteristics and origins are described in Table 1. Pseudomonas s. syringae 31 is a fluorescent (Flu ${ }^{+}$), ice-nucleation active (Ina ${ }^{+}$), epiphytic strain originally isolated from a corn leaf surface (Arny et al., 1976). Strain JL2000 (31R1), a

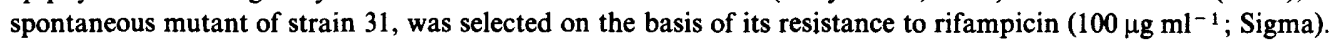
The broad host range cloning vector, pLAFR1 (Friedman et al., 1982), a cosmid, is a $21 \cdot 6-\mathrm{kb}$ derivative of plasmid pRK290 (Ditta et al., 1980) which carries the cohesive ends site (cos) of bacteriophage $\lambda$, has a single $E c o$ RI restriction enzyme site suitable for cloning DNA fragments, and confers resistance to tetracycline. The recombinant helper plasmid, pRK2013, carries the conjugal transfer gene system and kanamycin resistance marker of RK2 linked to the ColE1 replicon (Figurski \& Helinski, 1979; Ditta et al., 1980).

Isolation of nonfluorescent $\left(F^{-} u^{-}\right)$mutants of P. s. syringae. Mutants of JL 2000 deficient in fluorescent pigment production were derived by chemical mutagenesis with ethyl methanesulphonate (methanesulphonic acid ethyl ester; EMS) to achieve $90 \%$ killing of bacterial cells. Strain JL2000 was grown in KBM (King et al., 1954) broth to exponential phase, $5 \%(\mathrm{v} / \mathrm{v})$ EMS was added, mixed well, and incubated $\left(25^{\circ} \mathrm{C}\right)$ with shaking for $20 \mathrm{~min}$. 
Table 1. Origin and characteristics of bacterial strains

Strain JL2000 and its derivatives did not contain indigenous plasmids detectable by methods cited in the text.

\begin{tabular}{|c|c|c|c|}
\hline \multirow[b]{2}{*}{ Strain no. } & \multicolumn{2}{|c|}{ Relevant genetic and phenotypic markers* } & \multirow[b]{2}{*}{ Origin } \\
\hline & Chromosomal & Plasmid & \\
\hline \multicolumn{4}{|l|}{ Escherichia coli } \\
\hline HB101 & $\begin{array}{l}\mathrm{F}^{-} h s d S 20\left(\mathrm{r}_{\mathrm{B}-} \mathrm{m}_{\mathrm{B}-}\right) \text { recA13 } \\
\text { ara-14 proA2 lacYI galK2 } \\
\text { rpsL20 (Str-r) xyl-5 mtl-1 } \\
\text { supE44 } \lambda^{-}\end{array}$ & None & N. Panopoulos \\
\hline JL1101 & As above & $\begin{array}{l}\text { pLAFR1 } \\
\left(\text { Tet }^{r} \cos t r a^{-} r l x^{+}\right)\end{array}$ & $\begin{array}{l}\text { HB101(pLAFR1); S. Long } \\
\text { (Friedman et al., 1982) }\end{array}$ \\
\hline JL1102 & As above & pRK2013 $\left(\right.$ Kan $\left.^{r} \operatorname{tra}^{+}\right)$ & $\begin{array}{l}\text { HB101(pRK2013); S. Long } \\
\text { (Ditta et al., 1980) }\end{array}$ \\
\hline JL1010 & As above & $\begin{array}{l}\text { pSFL10 } \\
\quad\left(\text { Tet }^{r} \cos \text { tra }^{-} r l x^{+}\right)\end{array}$ & See text \\
\hline JL1011 & As above & $\begin{array}{l}\text { pSFL11 } \\
\quad\left(\text { Tet }^{\mathrm{r}} \cos t r a^{-} r l x^{+}\right)\end{array}$ & See text \\
\hline JL1012 & As above & $\begin{array}{l}\text { pSFL12 } 12 \dagger \\
\left(\text { Tet }^{\mathrm{r}} \cos \mathrm{tra}^{-} r \mathrm{rl}^{+}\right)\end{array}$ & See text \\
\hline JL1014 & As above & $\begin{array}{l}\text { pSFL14 } \\
\left(\text { Tet }^{\mathrm{r}} \cos \mathrm{tra}^{-} \text {rlx } x^{+}\right)\end{array}$ & See text \\
\hline \multicolumn{4}{|c|}{ Pseudomonas syringae pv. syringae } \\
\hline JL2000 & $\mathrm{Flu}^{+}$Ina ${ }^{+}$Rifr $^{r} \mathrm{Eda}^{+}$ & $-\ddagger$ & $\begin{array}{l}\text { 31R1; S. Lindow (Arny et al. } \\
\text { 1976) }\end{array}$ \\
\hline JL2003, JL2023 & $\mathrm{Flu}^{-} \mathrm{Ina}^{+} \mathrm{Rif}^{\mathrm{r}} \mathrm{Eda}^{-}$ & $-\ddagger$ & $\begin{array}{l}\text { EMS mutagenesis of JL2000 } \\
\text { (see text) }\end{array}$ \\
\hline JL2087, JL2088 & $\mathrm{Flu}^{-} \mathrm{Ina}^{+} \mathrm{Rif}^{\mathbf{r}} \mathrm{Eda}^{+}$ & $-\ddagger$ & $\begin{array}{l}\text { EMS mutagenesis of JL2000 } \\
\text { (see text) }\end{array}$ \\
\hline JL2140 & Flu $^{-}$Ina- ${ }^{-}$if $^{r} \mathrm{Eda}^{-}$ & $-\ddagger$ & $\begin{array}{l}\text { 31R1-26; S. Lindow (Lindow } \\
\text { \& Staskawicz, 1981) }\end{array}$ \\
\hline
\end{tabular}
KBM-EDDA $\left(200 \mu \mathrm{g} \mathrm{ml}^{-1}\right)$; Flu ${ }^{+}$, fluorescent pigment production; Ina ${ }^{+}$, ice nucleation activity. Rif, Kan, Tet, and Str refer to rifampicin, kanamycin, tetracycline and streptomycin. Superscript $\mathbf{r}$ or $\mathbf{s}$ refers to relative resistance or susceptibility. $\cos =$ cohesive ends site of phage $\lambda . t r a^{+}=$conjugative plasmid transfer. $r l x^{+}=$ relaxation site.

† Prefix registered with the Plasmid Reference Center, Department of Medical Microbiology, Stanford University, Stanford, Calif., USA.

$\ddagger$ No indigenous plasmids have been detected in strain JL2000 or its derivatives in repeated attempts using standard methods described in text.

Mutagenized cells were washed twice, resuspended in KBM broth, and incubated for $2 \mathrm{~h}$ to allow chromosome segregation and phenotypic lag (Miller, 1972). Segregated cells were then plated on KBM agar at cell densities of 30-50 c.f.u. per plate. After $2 \mathrm{~d}$ incubation at $25^{\circ} \mathrm{C}$, Flu- mutants were detected by observation under UV irradiation $(366 \mathrm{~nm})$.

Construction of genomic library. A genomic library, designated PssLIB2, was constructed by cloning total DNA from $P$. s. syringae strain JL2000 in Escherichia coli HB101 (Orser et al., 1983) using the methods of Friedman et al. (1982). The DNA was extracted following cell lysis in a Tris/sucrose/EDTA/lysozyme mixture [50 mM-Tris buffer, pH 7.8, 25\% (w/v) sucrose, 5 mM-EDTA, $1 \mathrm{mg}$ lysozyme $\mathrm{ml}^{-1}$ ], banding twice in caesium chloride/ethidium bromide density gradients using a Beckman vertical rotor at 45000 r.p.m. for 20 h, dialysis of the DNA containing fractions in Tris/EDTA buffer (10 mM-Tris, pH 8.0, 1 mM-EDTA) and sequential precipitation of the DNA with $1 \mathrm{vol}$. isopropanol and $2 \mathrm{vol} .95 \%(\mathrm{v} / \mathrm{v})$ ethanol. The final pellet was resuspended in $10 \mathrm{~mm}$-Tris, $1 \mathrm{mm-EDTA \text {, }}$ pH 8.0, and subjected to partial digestion with EcoRI restriction endonuclease (0.3 units per $\mu \mathrm{g}$ DNA; Bethesda Research Laboratories (BRL), Rockville, Md., USA). The reaction was stopped by heating at $65^{\circ} \mathrm{C}$ for $4 \mathrm{~min}$. The DNA was fractionated by sucrose gradient centrifugation $(5-25 \%$ sucrose, 20000 r.p.m., $18 \mathrm{~h}$ ) and $20 \mu \mathrm{l}$ portions of the fractions were electrophoresed on ethidium bromide/agarose gels $\left(0.5 \mu \mathrm{g}\right.$ ethidium bromide $\mathrm{ml}^{-1}, 0.7 \%$ agarose, $40 \mathrm{~mm}$-Tris, $20 \mathrm{~mm}$-acetic acid, $2 \mathrm{~mm}-\mathrm{Na}_{2}$ EDTA buffer, pH 8.1). The fractions rich in 18-25 kb fragments were pooled, precipitated with ethanol and resuspended in sterile distilled water to a final concentration of $1 \mu \mathrm{g} \mathrm{ml}^{-1}$. DNA of the cosmid vector pLAFR1 was similarly purified and digested to completion with EcoRI. 
One $\mu \mathrm{l}$ of this preparation and $4 \mu \mathrm{l}$ of genomic DNA fragments ( 1 and $4 \mu \mathrm{g}$, respectively) were mixed and sequentially incubated at $65^{\circ} \mathrm{C}$ for $2 \mathrm{~min}$, at $42{ }^{\circ} \mathrm{C}$ for $30 \mathrm{~min}$, and at room temperature for $2 \mathrm{~h}$. Ligation was performed in the presence of a total of 5 units of T4 DNA ligase (BRL) and $1 \mathrm{mM}-\mathrm{ATP}$ at $12^{\circ} \mathrm{C}$ overnight. In vitro packaging extracts were prepared from strains BHB2690 and BHB2688 as described in Maniatis et al. (1982). For packaging, $30 \mu \mathrm{l}$ of sonic extract and $20 \mu \mathrm{l}$ of freeze-thaw extract, $2 \mu \mathrm{l}$ of $1 \mathrm{mM}$-ATP and $5 \mu \mathrm{l}$ of ligated DNA were mixed and incubated at room temperature for $1 \mathrm{~h}$. One $\mathrm{ml}$ of a dilution buffer $\left(10 \mathrm{mM}-\mathrm{MgCl}_{2}, 10 \mathrm{mM}\right.$-Tris buffer, $\mathrm{pH} 7.6$ ) was added and the samples were stored at $4{ }^{\circ} \mathrm{C}$. For transduction, $0.1 \mathrm{ml}$ of the above phage stock was mixed with $0.5 \mathrm{ml}$ of $E$. coli $\mathrm{HB} 101$ cells grown to mid-exponential phase $\left(10^{7}-10^{8} \mathrm{cells}^{-1}\right)$ in Luria broth (Miller, 1972) supplemented with $0.4 \%$ maltose and incubated for $1 \mathrm{~h}$ at $37^{\circ} \mathrm{C}$. Two ml Luria broth was then added and the cells were allowed to grow for $1.5-2 \mathrm{~h}$ at $37^{\circ} \mathrm{C}$. Transductants (hereafter referred to as $E$. coli clones) harbouring recombinant plasmids were selected on Luria agar supplemented with $15 \mu \mathrm{g}$ tetracycline $\mathrm{ml}^{-1}$.

DNA analysis. Rapid isolation of plasmid DNA was done by an alkaline extraction procedure as described by Birnboim \& Doly (1979) or by the boiling lysis procedure described by Maniatis et al. (1982). Restriction endonuclease digestions and agarose gel electrophoresis were performed as described by Maniatis et al. (1982).

Transfer of recombinant plasmids to Flu- mutants. The conjugative plasmid, pRK2013, which mobilizes the vector, pLAFR1, was used as a helper element to transfer the recombinant plasmids of PssLIB2 to recipient Flu mutants in triparental matings (Ditta et al., 1980). These matings were carried out as follows. Exponential phase cultures of the entire PssLIB2 library (en masse matings) or of individual E. coli clones, JL1102, and individual $\mathrm{Flu}^{-}$mutants were mixed to a concentration of approximately $10^{8}, 10^{8}$ and $3 \times 10^{9}$ c.f.u. $\mathrm{ml}^{-1}$ respectively, and placed on $0.2 \mu \mathrm{m}$ membrane filters (Millipore). The filters were incubated overnight on KBM agar before the cells were suspended in $100 \mathrm{mM}-\mathrm{MgSO}_{4}$, serially diluted and plated on KBM agar containing rifampicin (Rif, $100 \mu \mathrm{g} \mathrm{ml}^{-1}$ ) and tetracycline (Tet, $15 \mu \mathrm{g} \mathrm{ml}^{-1}$ ) to select for Tet ${ }^{\mathrm{r}}, \mathrm{Rif}^{\mathrm{r}}$ transconjugants. These transconjugants were screened for fluorescent pigment production after incubation ( $4 \mathrm{~d})$ at $25^{\circ} \mathrm{C}$ by illuminating the selection plates with UV (366 nm).

Alternatively, each of 718 E. coli clones of PssLIB2 were mixed with JL1102 and individual Flu- mutants on KBM in separate wells of microtitre plates. The microtitre plates were incubated for $18-24 \mathrm{~h}$ at $25^{\circ} \mathrm{C}$. $\operatorname{Rif}^{\mathrm{r}}, \mathrm{Tet}^{\mathrm{T}}$ transconjugants of $P$. s. syringae were obtained by transferring cells from the microtitre plates to selective medium with a 49-prong replicator. Restoration of fluorescence was scored as described above.

Fluorescent $P$. s. syringae transconjugant colonies were purified and used as donors in individual triparental matings as above but with $\mathrm{HB} 101$ as a recipient. Exponential phase cultures of individual $P$. $s$. syringae transconjugant strains, JL1102, and $\mathrm{HB} 101$ were mixed to a concentration of approximately $10^{9}$, $10^{8}$, and $10^{8}$ c.f.u. $\mathrm{ml}^{-1}$ respectively, placed on $0.2 \mu \mathrm{m}$ membrane filters, and incubated overnight on Luria agar plates. $\mathrm{Tet}^{\mathrm{r}}, \mathrm{Str}^{\mathrm{r}}$ transconjugants of $E$. coli $\mathrm{HB} 101$ were selected on Luria medium containing streptomycin (Str, $\left.15 \mu \mathrm{g} \mathrm{ml}^{-1}\right)$ and tetracycline $\left(15 \mu \mathrm{g} \mathrm{ml}^{-1}\right)$. To confirm the ability of each recombinant cosmid to restore fluorescence to the original $\mathrm{Flu}^{-}$mutant after retransfer to $E$. coli, purified $\mathrm{Tet}^{\mathrm{r}}$, Str ${ }^{\mathrm{r}}$ transconjugants from the above crosses were used as donors in triparental matings with $\mathrm{Flu}^{-} P$. s. syringae recipients.

The fluorescence of some $P$. s. syringae transconjugants was unstable upon subculture. The transconjugant strains discussed in this paper are those which expressed the fluorescence phenotype stably through several sequential single-colony transfers on selective medium (KBM with rifampicin and tetracycline).

Conditions of iron-limited growth. KBM agar was supplemented with EDDA (200 $\mu \mathrm{g} \mathrm{ml}^{-1}$; Sigma), resulting in a medium (KBM-EDDA) with low levels of available iron. The EDDA solution was prepared as described by Ong et al. (1979) after removing iron as described by Rogers (1973). KBM agar supplemented with EDDA was allowed to stand for at least $24 \mathrm{~h}$ at $4{ }^{\circ} \mathrm{C}$ prior to use to allow slow chelation of iron. The specificity of EDDA chelation for the ferric ion is discussed in Archibald \& De Voe (1980). Bacterial suspensions were adjusted to a uniform density of $0 \cdot 1 \mathrm{OD}_{640}$ unit and streaked with a calibrated $1 \mu$ loop on KBM-EDDA medium. Only four suspensions were streaked on each plate to negate the influence of cross-feeding. Iron-limited growth inhibition is reversed by addition of a freshly prepared, filter-sterilized solution of $10^{-2} \mathrm{M}-\mathrm{FeCl}_{3}$ to the $\mathrm{KBM}$-EDDA medium to a final concentration of $10^{-4} \mathrm{M}-\mathrm{FeCl}_{3}$.

\section{RESULTS}

\section{EMS mutagenesis}

Nonfluorescent mutants of $P$. s. syringae strain JL2000 arose at a frequency of $0 \cdot 1-0.5 \%$ of cells plated following EMS mutagenesis. No spontaneous Flu ${ }^{-}$mutants of JL2000 were observed in cultures not subjected to EMS mutagenesis. A total of $146 \mathrm{Flu}^{-}$mutants were selected for use as recipients in triparental matings with PsSLIB2. Many of these mutants failed to grow on an iron-deficient medium (KBM-EDDA), a phenotype designated here as Eda ${ }^{-}$(see Table 1). Reversion of the mutants to Flu ${ }^{+}$and $\mathrm{Eda}^{+}$was never observed. Since no direct 
selection for $\mathrm{Flu}^{+}$or $\mathrm{Eda}^{+}$is available (growth on KBM-EDDA is dependent on plating density, presumably due to cross-feeding among cells), the exact reversion frequency could not be determined. Nevertheless, the fact that only certain recombinant plasmids were able to restore fluorescence to a given group of $\mathrm{Flu}^{-}$mutants while others consistently failed to do so (see below) provides an internal control which obviates the need for more accurate reversion frequency estimates for the interpretation of data presented below.

\section{Fluorescence restoration experiments}

En masse matings of PssLIB2 with one Flu ${ }^{-}$mutant, JL2140, yielded Tet ${ }^{\mathrm{r}}$ transconjugants at a frequency of approximately $1.5 \times 10^{-4}$ per recipient. Triparental matings of JL2140 with 718 individual $E$. coli clones comprising the genomic library resulted in the identification of two recombinant plasmids producing $\mathrm{Flu}^{+}$transconjugants. EcoRI restriction endonuclease digestion patterns of the recombinant plasmids isolated from both $E$. coli donors were identical indicating that these donors were probably duplicate clones stored separately in microtitre plates. The plasmid common to both clones was designated pSFL10 and the HB101 clone harbouring this plasmid was named JL1010.

Plasmid pSFL10 was subsequently transferred by individual triparental matings of JL1010 with 145 additional Flu- mutants of $P$. s. syringae strain JL2000. Tet transconjugants were selected in every case at frequencies of $9 \times 10^{-5}$ to $1 \times 10^{-3}$, but fluorescence was restored in only $10 \mathrm{Flu}^{-}$mutants (including JL2140) upon introduction of pSFL10.

Seven $\mathrm{Flu}^{-}$mutants which were not restored to $\mathrm{Flu}^{+}$upon introduction of pSFL10 were individually mated with JL1102 and each of the 718 members of the DNA genomic library. Three E. coli clones, JL1011, JL1012 and JL1014, were identified which gave $\mathrm{Tet}^{\mathrm{r}}$, Flu ${ }^{+}$ transconjugants upon transfer to one or more of the seven $\mathrm{Flu}^{-}$mutant strains. Each of these $E$. coli clones was then mated separately with each of the $146 \mathrm{Flu}^{-}$mutants. In every case, Tet ${ }^{\mathrm{r}}$ transconjugants could be selected at similar frequencies as in previous crosses. The numbers of $\mathrm{Flu}^{-}$mutants yielding $\mathrm{Flu}^{+}$transconjugants in these crosses were 10,11 and 5 for JL1011, JL1012, and JL1014 respectively (Table 2). None of the mutants were restored to $\mathrm{Flu}^{+}$by mating with more than one of the four $E$. coli clones.

These experiments define four fluorescence restoration groups, designated as groups 10,11, 12 and 14 (Table 2) and defined for the purposes of this study as an E. coli strain harbouring a recombinant plasmid and a group of 5 to $11 \mathrm{Flu}^{-}$mutants of $P$. s. syringae strain JL2000 for which fluorescence was restored by that clone. One or more representative mutants from each fluorescence restoration group are given in Table 2 . Whereas a total of $36 \mathrm{Flu}^{-}$mutants were restored to $\mathrm{Flu}^{+}$in these experiments, the remaining 110 mutants were not restored by any of the

\section{Table 2. Fluorescence restoration groups and iron-limited growth of $P$. s. syringae strains}

Individual triparental matings of the four $E$. coli plasmid donors with each of the 146 nonfluorescent mutants yielded $\mathrm{Tet}^{r}$ transconjugants in every case. The number of mutants yielding $\mathrm{Flu}^{+}, \mathrm{Tet}^{\mathrm{r}}$ transconjugants in matings with $E$. coli donors is given in column 4. All nonfluorescent mutants and fluorescent transconjugants grew on KBM and on KBM-EDDA supplemented with $10^{-4} \mathrm{M}-\mathrm{FeCl}_{3}$. All fluorescent transconjugants grew on KBM-EDDA.

\begin{tabular}{cccccc}
$\begin{array}{c}\text { Fluorescence } \\
\text { restoration } \\
\text { group }\end{array}$ & $\begin{array}{c}\text { E. coli } \\
\text { donor } \\
\text { strain }\end{array}$ & $\begin{array}{c}\text { Recombinant } \\
\text { plasmid }\end{array}$ & $\begin{array}{c}\text { No. of Flu } \\
\text { mutants restored } \\
\text { to Flu }\end{array}$ & \multicolumn{2}{c}{$\begin{array}{c}\text { Growth of representative nonfluorescent } \\
\text { mutants on KBM-EDDA }\end{array}$} \\
10 & JL1010 & pSFL10 & 10 & Strain & Growth \\
11 & JL1011 & pSFL11 & 10 & JL2140 & - \\
12 & JL1012 & pSFL12 & 11 & JL2003 & - \\
14 & JL1014 & pSFL14 & 5 & JL2023 & - \\
& & 5 & JL2088 & $+^{*}$
\end{tabular}

* Strain JL2088 grew on KBM-EDDA plates, but exhibited no visible fluorescence on KBM or KBM-EDDA. † Strain JL2087 grew and exhibited weak fluorescence on KBM-EDDA but exhibited no visible fluorescence on KBM. 
four plasmids. We presume that these mutants carried mutation(s) in genes which had not been cloned or had been inactivated by endonuclease digestion. It is also possible that, given the severe mutagenic treatment employed, these mutants carried multiple mutations that were not clustered within the DNA fragments carried by these plasmids.

\section{Structural analysis of recombinant plasmids}

Digestion of DNA of the four recombinant plasmids (pSFL10, pSFL11, pSFL12, pSFL14) isolated from the original $E$. coli clones with the restriction endonuclease $E c o R I$ indicated that the four recombinant plasmids were structurally distinct (Fig. 1).

Repeated attempts to demonstrate the presence of a plasmid with an Eco RI restriction pattern having a $21.6 \mathrm{~kb}$ fragment corresponding to pLAFR 1 in any of the $P$. s. syringae transconjugants of Table 2 were unsuccessful. That these transconjugants had indeed acquired recombinant plasmids following conjugation was determined indirectly as follows. Four individual $\mathrm{Flu}^{+}$, $\mathrm{Tet}^{\mathrm{r}}$ transconjugants from each of the four complementation groups were utilized as donors in triparental matings with $\mathrm{JL} 1102$ and $E$. coli $\mathrm{HB} 101$ as the recipient. Tetr, $S t r^{r}$ transconjugants were selected at a frequency of approximately $10^{-5}$ per recipient. Several

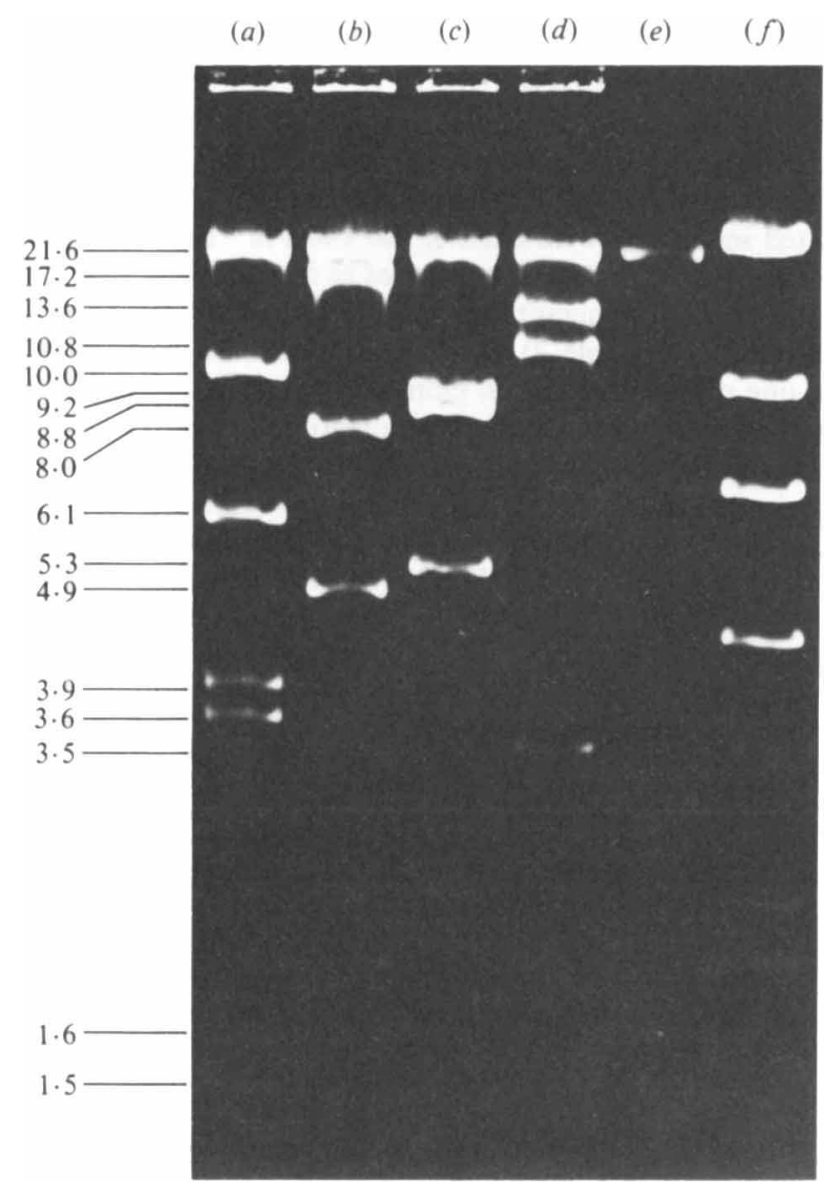

Fig. 1. Agarose gel electrophoresis of EcoRI-generated fragments of recombinant plasmids: (a) pSFL14, $(b)$ pSFL12, $(c)$ pSFL11, $(d)$ pSFL10 and (e) pLAFR1. Purified plasmid DNA was cut with EcoRI and fractionated on a $0.7 \%(\mathrm{w} / \mathrm{v})$ agarose gel in Tris/acetate buffer (Maniatis et al., 1982) at $120 \mathrm{~V}, 60 \mathrm{~mA}$ for $4 \mathrm{~h}$. Lane $(f)$ is phage $\lambda$ cut with the restriction endonuclease HindIII. Numbers represent DNA sizes in $\mathrm{kb}$. 
transconjugants from each cross were analysed for their plasmid content following EcoRI digestion. In most cases, the EcoRI restriction fragment patterns observed were composites of the two fragments of pRK2013 and those of the recombinant plasmid (pSFL10, pSFL11, pSFL12, or pSFL14) isolated from the original recombinant clones. A small percentage of the $\mathrm{Tet}^{\mathrm{r}}, \mathrm{Str}^{\mathrm{r}}$ transconjugants contained fragments corresponding to those of the original recombinant cosmid but lacked the pRK2013 fragments. The presence of the pRK2013 fragments always correlated with resistance to kanamycin, conferred by this plasmid. These recombinant plasmids were functionally intact after transfer to $E$. coli since reintroduction to mutants within their respective fluorescence restoration groups was accompanied by restoration of the $\mathrm{Flu}^{+}$phenotype.

\section{Expression of iron-limited growth phenotype}

The fluorescent, wild-type $P$. s. syringae strain $\mathrm{JL2000}$ and all $\mathrm{Flu}^{+}$transconjugants grew on the iron-limiting medium, KBM-EDDA, while $\mathrm{Flu}^{-}$mutants of different fluorescence restoration groups differed in their growth (Table 2). Addition of $10^{-4} \mathrm{M}-\mathrm{FeCl}_{3}$ to $\mathrm{KBM}$-EDDA reversed the growth inhibition in every case, presumably because of increased iron availability. All Flu- mutants of groups 10 and 11 were unable to grow on KBM-EDDA, as exemplified by strains JL2140 and JL2003, respectively. In contrast, all Flu- mutants of complementation group 14 grew on KBM-EDDA, as exemplified by strain JL2087. Furthermore, all mutants of group 14, while nonfluorescent on KBM, did fluoresce slightly on KBM-EDDA. Flu- mutants of group 12 fell into two groups on the basis of their ability to grow on KBM-EDDA. Seven mutants of group 12 (subgroup 12a) exhibited growth patterns similar to the Flu- mutants of groups 10 and 11 . The behaviour of these mutants is exemplified by strain JL2023, which was unable to grow on KBM-EDDA. Four Flu ${ }^{-}$mutants of group 12 (subgroup 12b) did grow on KBM-EDDA, as exemplified by strain JL2088. However, these mutants differed from those of fluorescence restoration group 14 in that they were nonfluorescent on both KBM and KBMEDDA.

\section{DISCUSSION}

At least four distinct genes or gene clusters are involved in fluorescent pigment biosynthesis of $P$. s. syringae. Four recombinant plasmids, containing DNA fragments involved in some aspect of fluorescent pigment production, were distinct structurally, in their EcoRI restriction patterns, and functionally, in their lack of overlap in fluorescence restoration. Nonfluorescent mutants of fluorescence restoration group 12 fell into two groups based on their growth under iron-limiting conditions. Two or more genes involved in distinct aspects of fluorescent siderophore production may be present on the DNA fragment(s) cloned on the recombinant plasmid pSFL12, which restored these mutants with respect to fluorescence. The lack of any common $E c o$ RI fragments among the four recombinant cosmids analysed suggests that the genes for fluorescent pigment (siderophore) biosynthesis in $P$. s. syringae are located in at least four distinct gene clusters. In contrast, genes for biosynthesis of the high-affinity siderophores, aerobactin and enterobactin, in $E$. coli are in single gene clusters within a $16.3 \mathrm{~kb}$ fragment (aerobactin, Bindereif \& Neilands, 1983) or a $26 \mathrm{~kb}$ fragment (enterobactin, Laird \& Young, 1980; Laird et al., 1980). Generally, lack of clustering of functionally related genes is more common in Pseudomonas spp. than in the enteric bacteria (Holloway et al., 1979).

Studies analysing the structure of fluorescent siderophores of $P$. fluorescens have identified both hydroxymate groups involved in iron chelation and a fluorescent chromophore on the same molecule (Teintze et al., 1981; Philson \& Llinas, 1982b). Mutants deficient in the production of this fluorescent siderophore are expected to be deficient both in fluorescence and in their ability to grow under iron-limiting conditions. Flu ${ }^{-}$mutants of groups 10 and 11 and of sub-group 12a exhibited these pleiotropic functions, as expected. However, other mutants, either completely or partially deficient in fluorescence, grew but differed in their fluorescence under iron-limiting conditions. $\mathrm{Flu}^{-}$mutants of fluorescence restoration group 14 were slightly fluorescent on ironlimiting medium whereas those of sub-group $12 \mathrm{~b}$ were not. One can envisage that mutants of 
group 14 are altered in their iron regulation. That is, although the fluorescent siderophore is not produced by these mutants on KBM as in the wild-type strain, production does occur under more iron-limiting conditions. Nonpleiotropic mutants of sub-group $12 \mathrm{~b}$ may produce reduced levels of the fluorescent siderophore that are sufficient for iron-limited growth but insufficient for visible fluorescence. Alternatively, these mutants may be altered only in the synthesis or attachment of the fluorescent chromophore of the siderophore, retaining at least reduced ironchelating and transport functions of this molecule. Ferribactin and pseudobactin A, siderophores structurally related to pyoverdine and pseudobactin but lacking the functional fluorescent chromophore of these compounds, have been isolated from $P$. fluorescens (Teintze \& Leong, 1981; Philson \& Llinas, 1982a,b). The chemical structures of pseudobactin and pseudobactin A, siderophores isolated from culture filtrates of $P$. fluorescens strain B10, differ only in the absence of a double bond in the fluorescent chromophore of pseudobactin. The siderophore produced by nonpleiotropic mutants of sub-group $12 \mathrm{~b}$ may be analogous to ferribactin or pseudobactin A, exhibiting at least reduced iron-chelating and transport functions but not fluorescence.

A large number of $\mathrm{Flu}^{-}$mutants could not be restored to $\mathrm{Flu}^{+}$by the four recombinant plasmids identified in this study. The existence of additional genes or gene clusters involved in fluorescent pigment biosynthesis of $P$. s. syringae is not definitive at this time.

\section{REFERENCES}

ARChibald, F. S. \& De Voe, I. W. (1980). Iron acquisition by Neisseria menigitidis in vitro. Infection and Immunity 27, 322-334.

ARNY, D. C., Lindow, S. E. \& UPPER, C. D. (1976). Frost sensitivity of Zea mays increased by application of Pseudomonas syringae. Nature, London 262, 282-284.

BachmanN, B. J. \& Low, K. B. (1980). Linkage map of Escherichia coli K-12, edition 6. Microbiological Reviews 44, 1-56.

Bindereif, A. \& Neilands, J. B. (1983). Cloning of the aerobactin-mediated iron assimilation system of plasmid ColV. Journal of Bacteriology 153, 11111113.

BIRNBOIM, H. C. \& DolY, J. (1979). A rapid alkaline extraction procedure for screening recombinant plasmid DNA. Nucleic Acids Research 7, 1513-1523.

Bulen, W. A. \& Le Comte, J. R. (1962). Isolation and properties of a yellow-green fluorescent peptide from Azotobacter medium. Biochemical and Biophysical Research Communications 9, 523-528.

BURR, T. J. \& CAESAR, A. J. (1984). Beneficial plant bacteria. CRC Critical Reviews in Plant Science (in the Press).

Corbin, J. L., Karle, I. L. \& Karle, J. (1970). Crystal structure of the chromophore from the fluorescent peptide produced by iron-deficient Azotobacter vinelandii. Chemical Communications 1970, 186-187.

Ditta, G., Stansfield, S., Corbin, D. \& Helinski, D. R. (1980). Broad host range DNA cloning system for Gram-negative bacteria: construction of a gene bank of Rhizobium meliloti. Proceedings of the National Academy of Sciences of the United States of America 77, 7347-7351.

Figurski, D. H. \& Helinski, D. R. (1979). Replication of an origin-containing derivative of plasmid RK2 dependent on a plasmid function provided in trans. Proceedings of the National Academy of Sciences of the United States of America 76, 1648-1652.
Friedman, A. M., Long, S. R., Brown, S. E., Buikema, W. J. \& Ausubel, F. M. (1982). Construction of a broad host range cosmid cloning vector and its use in the genetic analysis of Rhizobium mutants. Gene 18, 289-296.

Hemming, B. C., Orser, C., Jacobs, D. L., Sands, D. C. \& Strobel, G. A. (1982). The effects of iron on microbial antagonism by fluorescent pseudomonads. Journal of Plant Nutrition 5, 683-702.

Holloway, B. W., KRISHNapillai, v. \& MoRgan, A. F. (1979). Chromosomal genetics of Pseudomonas. Microbiological Reviews 43, 73-102.

Howell, C. R. \& Stipanovic, R. D. (1979). Control of Rhizoctonia solani on cotton seedlings with Pseudomonas fluorescens and with an antibiotic produced by the bacterium. Phytopathology 69, 480-482.

Howell, C. R. \& StIPANovic, R. D. (1980). Suppression of Pythium ultimum-induced damping-off of cotton seedlings by Pseudomonas fluorescens and its antibiotic, pyoluteorin. Phytopathology 70, 712-715.

King, E. O., Ward, M. K. \& Raney, D. E. (1954). Two simple media for the demonstration of pyocyanin and florescein. Journal of Laboratory and Clinical Medicine 44, 301-307.

Kloepper, J. W., LeONG, J., Teintze, M. \& Schroth, M. N. (1980). Enhanced plant growth by siderophores produced by plant growth-promoting rhizobacteria. Nature, London 286, 885-886.

LAIRD, A. J. \& Young, I. G. (1980). Tn5 mutagenesis of the enterochelin gene cluster of Escherichia coli. Gene 11, 359-366.

LAIRD, A. J., RibBons, D. W., Woodrow, G. C. \& YounG, I. G. (1980). Bacteriophage Mu-mediated gene transposition and in vitro cloning of the enterochelin gene cluster of Escherichia coli. Gene 11, 347-357.

LENHOFF, H. M. (1963). An inverse relationship of the effects of oxygen and iron on the production of fluorescin and cytochrome $c$ by Pseudomonas fluorescens. Nature, London 199, 601-602. 
LINDOW, S. E. \& STASKaWICZ, B. J. (1981). Isolation of ice nucleation deficient mutants of Pseudomonas syringae and Erwinia herbicola and their transformation with plasmid DNA. Phytopathology 71, 237 (abstract).

Loper, J. E., Orser, S. E., Panopoulos, N. J., SCHROTH, M. N. \& Lindow, S. E. (1983). Cosmid cloning of fluorescent siderophore genes from Pseudomonas syringae. Phytopathology 73, 826 (abstract).

Maniatis, T., Fritsch, E. F. \& SambrooK, J. (1982). Molecular Cloning, a Laboratory Manual. Cold Spring Harbor, New York: Cold Spring Harbor Laboratory.

MAurer, B., Müller, A., Keller-Schierlein, W. \& ZÄHNER, H. (1968). Ferribactin, a siderochrome from Pseudomonas fluorescens Migula. Archiv für Mikrobiologie 60, 326-339.

MCCracken, A. R. \& Swinburne, T. R. (1979). Siderophores produced by saprophytic bacteria as stimulants of germination of conidia of Colletotrichum musae. Physiological Plant Pathology 15, 331340.

Meyer, J. M. \& Abdallah, M. A. (1978). The fluorescent pigment of Pseudomonas fluorescens: biosynthesis, purification and physicochemical properties. Journal of General Microbiology 107, 319328.

MEYER, J. M. \& HoRNSPERGER, J. M. (1978). Role of pyoverdine, the iron-binding fluorescent pigment of Pseudomonas fluorescens, in iron transport. Journal of General Microbiology 107, 329-331.

MILLER, J. H. (1972). Experiments in Molecular Genetics. Cold Spring Harbor, New York: Cold Spring Harbor Laboratory.

Misaghi, I. J., Stowell, L. J., Grogan, R. G. \& SPEARMAN, L. C. (1982). Fungistatic activity of water-soluble fluorescent pigments of fluorescent pseudomonads. Phytopathology 72, 33-36.

Ong, S. A., Peterson, T. \& Neilands, J. B. (1979). Agrobactin, a siderophore from Agrobacterium tumefaciens. Journal of Biological Chemistry 254, 18601865.

Orser, C., Staskawicz, B. J., Loper, J. E., PanopouLOS, N. J., Lindow, S. E., DAhlbeCK, D. \& SCHROTH, M. N. (1983). Cloning of genes involved in bacterial ice nucleation and fluorescent pigment/siderophore production. In Molecular Genetics of the Bacteria-Plant Interaction, pp. 353-361. Edited by A. Puhler. Berlin: Springer-Verlag.
Panopoulos, N. J., Gumaraes, W. V., Hua, S.-S., SABersky-Lehman, C., Resnik, S., LAI, M. \& SHAFFER, S. (1978). Plasmids in phytopathogenic bacteria. In Microbiology - 1978, pp. 238-241. Edited by D. Schlessinger. Washington, DC: American Society for Microbiology.

Philson, S. B. \& Llinas, M. (1982a). Siderochromes from Pseudomonas fluorescens. I. Isolation and characterization. Journal of Biological Chemistry 257, 8081-8085.

Philson, S. B. \& Llinas, M. (1982b) Siderochromes from Pseudomonas fluorescens. II. Structural homology as revealed by NMR spectroscopy. Journal of Biological Chemistry 257, 8086-8090.

ROGERS, H. J. (1973). Iron-binding catechols and virulence in $E$. coli. Infection and Immunity 7, 445456.

SCHER, F. M. \& BAKer, R. (1982). Effect of Pseudomonas putida and a synthetic iron chelator on induction of soil suppressiveness to Fusarium wilt pathogens. Phytopathology 72, 1567-1573.

Schroth, M. N. \& HaNCock, J. G. (1981). Selected topics in biological control. Annual Review of Microbiology 35, 453-476.

Schroth, M. N. \& HaNCoCK, J. G. (1982). Diseasesupressive soil and root-colonizing bacteria. Science 216, 1376-1381.

Schroth, M. N., Hildebrand, D. C. \& StarR, M. P. (1981). Phytopathogenic members of the genus Pseudomonas. In The Prokaryotes, a Handbook on Habitats, Isolation, and Identification of Bacteria, vol. 1, pp. 701-718. Edited by M. P. Starr, H. Stolp, H. G. Truper, A. Balows \& H. G. Schlegel. Berlin: Springer-Verlag.

SusLow, T. V. (1982). Role of root-colonizing bacteria in plant growth. In Phytopathogenic Prokaryotes, vol. 1, pp. 187-223. Edited by M. S. Mount \& G. H. Lacy. New York: Academic Press.

Teintze, M. \& LeONG, J. (1981). Structure of pseudobactin $A$, a second siderophore from plant growth promoting Pseudomonas B10. Biochemistry 20, 64576462.

Teintze, M., Hossain, M. B., Barnes, C. L., Leong, J. \& VAN DER HeLM, D. (1981). Structure of ferric pseudobactin, a siderophore from a plant growth promoting Pseudomonas. Biochemistry 20, 64466457.

WeLleR, D. M. \& CoOK, R. J. (1983). Suppression of take-all of wheat by seed treatments with fluorescent pseudomonads. Phytopathology 73, 463-469. 